\title{
MICROPROPAGATION OF Capsicum chinense Jacq. cv. LOTA BHOT VIA INDIRECT ORGANOGENESIS
}

\author{
BORA G..$^{1,2 *}$, GOGOI H.K. ${ }^{1}$ AND HANDIQUE P.J. ${ }^{2}$ \\ 1Division of Biotechnology, Defence Research Laboratory (DRL), Tezpur- 784 001, Assam, India. \\ 2Department of Biotechnology, Gauhati University, Guwahati- 781 014, Assam, India. \\ *Corresponding Author: Email- geetashreejht@gmail.com
}

\author{
Received: May 03, 2014; Accepted: May 24, 2014
}

\begin{abstract}
Capsicum chinense Jacq. is well known for its pungency factor, "capsaicin". An attempt has been made to maintain the desired pungency of Capsicum chinense Jacq. cv. Lota Bhot through in vitro propagation via callusogenesis from leaf explants under the influence of different plant growth hormones and an additional component, Silver nitrate $\left(\mathrm{AgNO}_{3}\right)$. The combination of Kinetin $(45 \mu \mathrm{ML}-1)$ along with 2,4Dichlorophenoxy Acetic Acid (2,4-D) and $\mathrm{AgNO}_{3}$ at $3.5 \mu \mathrm{ML}^{-1}$ and $35 \mu \mathrm{ML}^{-1}$ respectively was found optimum for callus induction as well as multiple shoot induction whereas maximum shoot length was recorded at Kin $(40 \mu \mathrm{ML}-1)$, 2,4-D $\left(3.0 \mu \mathrm{ML}^{-1}\right)$ and $\mathrm{AgNO}_{3}\left(30 \mu \mathrm{ML}^{-1}\right)$. In vitro flower induction and fruit development was most observed under the influence of Gibberellic Acid $\left(\mathrm{GA}_{3}\right)$ at $30 \mu \mathrm{ML}^{-1}$. Murashige and Skoog (MS) medium fortified with Benzyl Amino Purine (BAP) ${ }^{1}$ and 2,4-D at $4.0 \mu \mathrm{ML}^{-1}$ and $5.5 \mu \mathrm{ML}^{-1}$ correspondingly was standardized for maximum induction of roots in vitro. Healthy in vitro regenerated plantlets were acclimatized in the potting substrate containing half strength MS medium enriched with soil, sand, vermicompost and vermiculite in all equal proportion and $78.56 \%$ of total acclimatized plants were successfully transferred to the main field.
\end{abstract}

Keywords- Lota Bhot, callusogenesis, In vitro flower induction, In vitro fruit development, Hardening, $\mathrm{GA}_{3}, \mathrm{AgNO}_{3}$

Citation: Bora G., Gogoi H.K. and Handique P.J. (2014) Micropropagation of Capsicum chinense Jacq. cv. Lota Bhot via Indirect Organogenesis. International Journal of Agriculture Sciences, ISSN: 0975-3710 \& E-ISSN: 0975-9107, Volume 6, Issue 1, pp.-384-387.

Copyright: Copyright@2014 Bora G., et al. This is an open-access article distributed under the terms of the Creative Commons Attribution License, which permits unrestricted use, distribution and reproduction in any medium, provided the original author and source are credited.

\section{Introduction}

Indian spices are one of the major reasons of breathing the country which helps in Indian economy as well. Among the various spices used in day to day basis, the most prevalent is chilli, or Capsicums. Chilli pepper or Capsicum species has been known since the beginning of civilization in the Western Hemisphere. The genus Capsicum is a member of the Solanaceae family that includes tomato, potato, tobacco, and petunia. So far, there exist approximately 22 wild species and five domesticated species of chilli: $C$. annuum $L$., C. baccatum L., C. chinense Jacq., C. frutescens L., and C. pubescens R. \& P. [1,2].

The one attribute most typical of chillies is pungency and must be considered one of its most important traits. The pungent factor lies within the seed and to some extent in the placenta nearby. Many innovative uses of pungency are being studied so far. Apart from having many valuable medicinal properties, it is extensively used as a barnacle repellent, to repel mice from all unwanted and hidden places and is effectively good to get rid of squirrels from eating its seeds. Moreover, to replace mace and tear gas, the pungent factor, capsaicin has been used widely as anti-mugger in more than a thousand police departments. Besides, the very effective pepper spray is to be considered as the first hand defensive tool for the protection of mankind especially women from most of the unfriendly situations.
Lota Bhot, a typical of $C$. chinense Jacq., is basically a green, round shaped, small sized, extremely pungent fruit which is heavily infested by birds in the field during cultivation. Though the crop is endemic to Assam, it is occasionally found and rarely cultivated under natural condition and which is why it could be considered as a rare type. This highly supports the fact that its extinguishing germplasm should be conserved urgently Commensurate with this, intervention of biotechnology or to be more precise, plant tissue culture for accelerating clonal multiplication of desired clones and strains of medicinal plants through micropropagation and their conservation through establishing Tissue Banks or Gene Banks are warranted in the right earnest. Even though there are several reports of In vitro regeneration on different domesticated species of Capsicum [1-15], there is no such report on indirect organogenesis of $C$. chinense $\mathrm{cv}$. Lota Bhot however.

Some of the rarely observed phenomena in the genus Capsicum are in vitro flower induction and fruit formation [16]. Growth hormone $\mathrm{GA}_{3}$ has several reports of in vitro flower development in different crops $[17,18] . \mathrm{GA}_{3}$ is known to regulate many physiological processes in plants like seed germination, shoot development and elongation, flower development etc. However for the development of in vitro flowers, there are other features too like genetic, hormonal and trophic factors [17]. Response of plants towards $\mathrm{GA}_{3}$ is also dependent on genotype, type of explants used, media com- 
position and culture conditions including temperature and photoperiod [17]. Another potent flower inducer is silver nitrate. Silver nitrate enhances flower induction by suppressing the action of ethylene $[11,19]$. It also has a profound effect on multiple shoot induction. So far there have been many reports of micropropagation in other chilli cultivars. However, this communicatio, brings into focus for the first time, the occurrence of in vitro organogenesis in the said chilli cultivar, Lota Bhot.

The present investigation has been designed with the idea of highlighting the regeneration potential of Lota Bhot utilizing various plant growth hormones and a vital component, $\mathrm{AgNO}_{3}$ in order to obtain indirect organogenesis via leaf explants.

\section{Materials and Methods}

Young healthy leaves of $C$. chinense cultivar, Lota Bhot (cultivated in the experimental area within Defence Research Laboratory), were taken for the purpose. Initially, the leaves were treated with $0.1 \%$ Bevistin solution (w/v) and kept for 15-20 minutes for indirect organogenesis via callus phase. Green leaves were washed thoroughly with doubled distilled water for about 3-4 times, subjected to surface sterilization with $70 \%$ alcohol $(5-10 \mathrm{sec})$, followed by mixing with an aqueous solution of 0.1 (w/v) $\mathrm{HgCl}_{2}$ for 3 min, finally rinsing with properly with sterile distilled water for 4-6 times to remove the traces of $\mathrm{HgCl}_{2}$. Leaf segments were cut aseptically from all sides in square shape [Fig-1a] and inoculated onto Murashige and Skoog (MS medium) [20] supplemented with growth hormones, KIN, 2,4-D and $\mathrm{AgNO}_{3}$ in different concentrations for induction of callus [Fig-1b] [Table-1]. MS medium was fortified with $3 \%[\mathrm{~m} / \mathrm{v}$ ] sucrose (Himedia, Mumbai, India) and $0.8 \%(\mathrm{~m} / \mathrm{v})$ Agar was used as a gelling agent.
The $\mathrm{pH}$ of the medium was set at 5.8 and autoclaved at $1.06 \mathrm{~kg} \mathrm{~cm}-$ 2 and $121^{\circ} \mathrm{C}$ for 15 min prior to inoculation. The cultures were incubated in dark for 7-10 days for induction of callus [Fig-1b] and subsequently brought to light of $16 \mathrm{~h}$ photoperiod using cool white fluorescent tubes at $25 \pm 2^{\circ} \mathrm{C}$ for growth of the callus. Green and friable calli were transferred to shoot induction medium supplemented with $\mathrm{KIN}, 2,4-\mathrm{D}$ and $\mathrm{AgNO}_{3}$ for induction of multiple shoots [Fig-1c],[Fig1d], [Table-1]. Healthy shoots $(1.5-2 \mathrm{~cm})$ were aseptically trimmed and transferred onto in vitro flower and fruit induction medium fortified with $\mathrm{GA}_{3}$ and $\mathrm{AgNO}_{3}$ [Fig-1f], [Fig-1g], [Table-2] and subsequently inoculated onto rooting medium fortified with 2,4-D and BAP [Fig-1e], [Table-3]. For acclimatization and hardening of in vitro raised seedlings, in vitro rooted plantlets were carefully taken out from the rooting medium and washed thoroughly with tap-water to remove of the traces of medium. These plantlets were transferred to perforated plastic cups containing half strength MS mixed with soil, sand, vermicompost and vermiculite $(1: 1: 1: 1)$ and kept in the poly house for 30-25 days [Fig-1h]. The top of the cup was covered with small perforated polythene bags for initial 10-15 days and plantlets were watered regularly to maintain high humid condition. However in the later period humidity was reduced by removing the polythene bags. Six-week-old hardened plants were finally transferred to the main field. Data were collected and the percentage of plant survival was recorded.

All the experiments were conducted with CRD and repeated thrice with each treatment having 10 replicates. Significance between treatments was calculated through One-Way ANOVA and differences among treatment means were based on Turkey's Honesty Significant difference (HSD at 0.05).

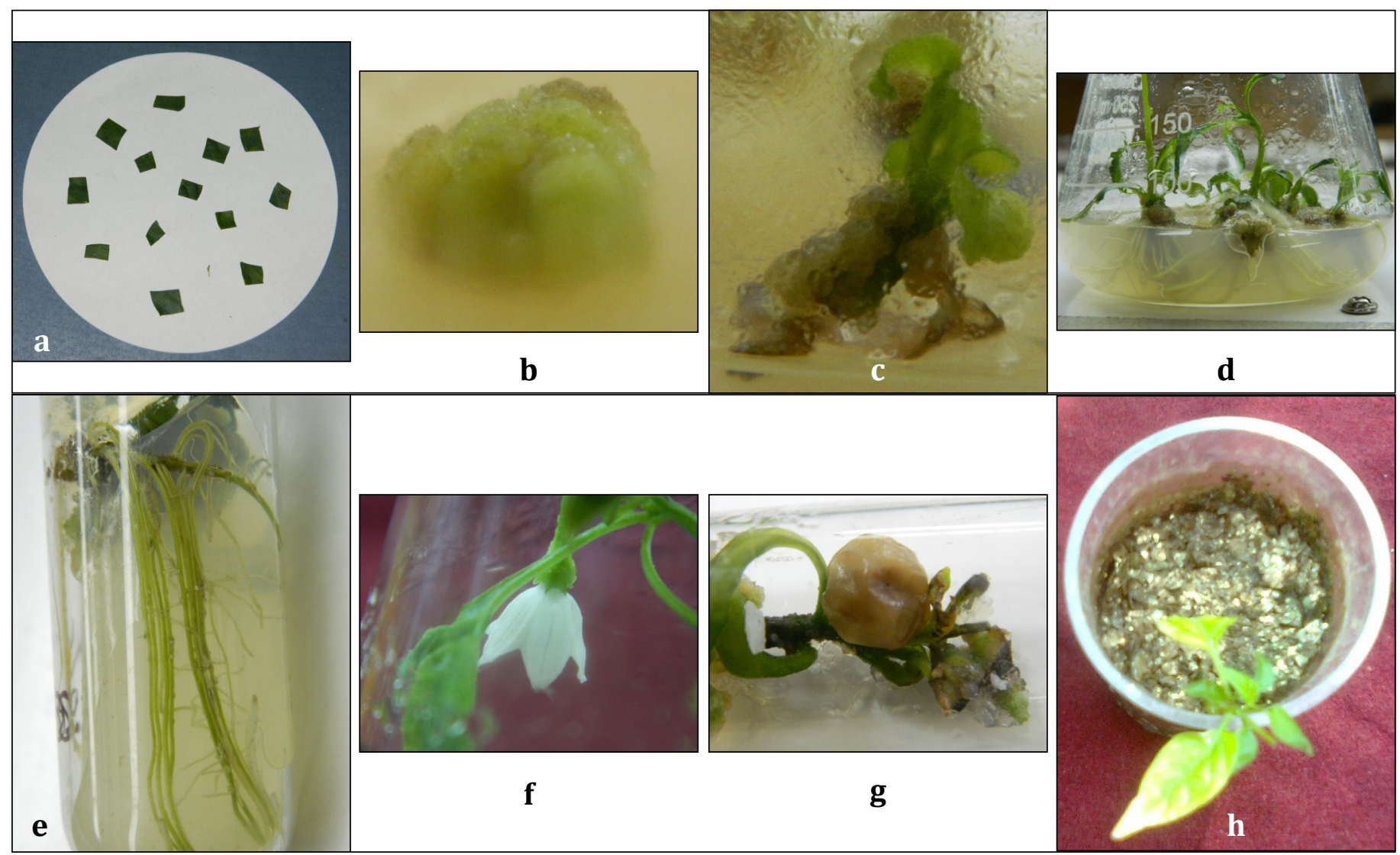

Fig. 1- Micropropagation of Lota Bhot (C. chinense) via indirect organogenesis: a) Leaf explants; b) Callus induction; c) In vitro shoot induction; d) Multiple shoot induction; e) In vitro root induction; f) In vitro flower induction; g) In vitro fruit induction; h) Hardening. 


\section{Results}

For maximum induction of callus and multiple shoots regeneration in vitro, the noble combination of $\mathrm{Kin}, 2,4-\mathrm{D}$ and $\mathrm{AgNO}_{3}$ at $45 \mu \mathrm{ML}^{-1}$, $3.5 \mu \mathrm{ML}^{-1}$ and $35 \mu \mathrm{ML}^{-1}$ respectively was recorded optimum wherein a mean of 43.1 numbers of leaf explants transformed into callus [Table-1], [Fig-1b]. A very high number of multiple shoot $(8.1 \pm 0.74)$ were induced from each callus at that very combination [Fig-1c], [Fig-1d]. But interestingly, maximum shoot length $(6.0 \pm 0.37)$ was achieved when the concentrations of Kin, 2,4-D and $\mathrm{AgNO}_{3}$ were slightly reduced to $40,3.0$ and $30 \mu \mathrm{ML}^{-1}$ correspondingly.

Flower induction and fruit formation in vitro from leaf explants responded effectively to the application of $\mathrm{GA}_{3}$ at $30 \mu \mathrm{ML}^{-1}$ [Table-2], [Fig-1f],[Fig-1g]. Maximum number of flower bud (14.7 \pm 1.31$)$ per explant, highest number of flower induction $(6.6 \pm 1.04)$ and fruit formation $(5.8 \pm 1.51)$ in vitro were observed when $\mathrm{GA}_{3}\left(30 \mu \mathrm{ML}^{-1}\right)$ single-handedly was supplemented to MS medium. On the other hand application of $\mathrm{AgNO}_{3}$ at $32 \mu \mathrm{ML}^{-1}$ without $\mathrm{GA}_{3}$ was quite significant in inducing a mean of 5.9 flowers; however only a mean of 3.3 flowers turned out into fruits finally. Furthermore it is worthwhile to mention that the combined effect of $\mathrm{GA}_{3}\left(28 \mu \mathrm{ML}^{-1}\right)$ and $\mathrm{AgNO}_{3}$ $\left(34 \mu \mathrm{ML}^{-1}\right)$ reduced the number of flower induction and fruit formation to a mean of 5.2 and 4.8 respectively.

Table 1- Effect of various media composition on in vitro callus induction, multiple shoot induction and shoot length in C. chinense cv. Lota Bhot

\begin{tabular}{ccccc|} 
S. No. & $\begin{array}{c}\text { Treatments MS+ } \\
\text { Kin+2,4-D+ Ag- } \\
\mathrm{NO}_{3}(\boldsymbol{\mu M} / \mathrm{L})\end{array}$ & $\begin{array}{c}\text { No. of Leaves } \\
\text { Forming Callus } \\
\text { (Mean } \pm S E)\end{array}$ & $\begin{array}{c}\text { No. of Multiple } \\
\text { Shoots/Callus } \\
\text { (Mean } \pm \text { SE) }\end{array}$ & $\begin{array}{c}\text { Shoot Length } \\
(\mathrm{cm}) \text { (Mean } \pm S E)\end{array}$ \\
\hline 1 & $20.0+1.0+10.0$ & $12.0 \pm 2.32 \mathrm{a}$ & $2.6 \pm 0.63 \mathrm{a}$ & $1.4 \pm 0.52 \mathrm{a}$ \\
2 & $25.0+1.5+15.0$ & $18.2 \pm 2.67 \mathrm{~b}$ & $3.5 \pm 0.55 \mathrm{a}$ & $3.4 \pm 0.26 \mathrm{~b}$ \\
3 & $30.0+2.0+20.0$ & $21.3 \pm 2.2 \mathrm{c}$ & $4.2 \pm 0.63 \mathrm{~b}$ & $4.4 \pm 0.54 \mathrm{c}$ \\
4 & $35.0+2.5+25.0$ & $30.7 \pm 4.13 \mathrm{~d}$ & $5.6 \pm 0.43 \mathrm{c}$ & $5.5 \pm 0.39 \mathrm{~d}$ \\
5 & $40.0+3.0+30.0$ & $37.4 \pm 1.59 \mathrm{e}$ & $6.9 \pm 0.67 \mathrm{~d}$ & $6.0 \pm 0.37 \mathrm{~d}$ \\
6 & $45.0+3.5+35.0$ & $43.1 \pm 1.21 \mathrm{f}$ & $8.1 \pm 0.74 \mathrm{~d}$ & $5.0 \pm 0.42 \mathrm{e}$ \\
7 & $50.0+4.0+40.0$ & $37.9 \pm 2.76 \mathrm{e}$ & $7.4 \pm 1.40 \mathrm{~d}$ & $4.8 \pm 0.37 \mathrm{c}$ \\
8 & $55.0+4.5+45.0$ & $35.6 \pm 3.23 \mathrm{~g}$ & $5.3 \pm 1.60 \mathrm{c}$ & $4.0 \pm 0.83 \mathrm{f}$ \\
9 & $60.0+5.0+50.0$ & $30.8 \pm 4.02 \mathrm{~d}$ & $4.0 \pm 1.35 \mathrm{~b}$ & $3.1 \pm 0.49 \mathrm{~b}$ \\
10 & $65.0+5.5+55.0$ & $22.5 \pm 4.33 \mathrm{c}$ & $4.0 \pm 0.86 \mathrm{~b}$ & $2.3 \pm 0.60 \mathrm{~g}$ \\
& & SE(Means)=1.2 & SE(Means) =1.33 SE(Means) $=0.59$ \\
\hline
\end{tabular}

Means followed by the same letters are not significantly different at $p=0.05$

Table 2- Effect of different concentrations of $\mathrm{GA}_{3}$ and $\mathrm{AgNO}_{3}$ on in vitro flower and fruit induction in $\mathrm{C}$. chinense $\mathrm{cv}$. Lota Bhot

\begin{tabular}{|c|c|c|c|}
\hline $\begin{array}{c}\text { Treatments } \\
\text { S. No. } \begin{array}{c}\text { MS+GA }+\mathrm{GA}_{3}+\mathrm{AgNO}_{3} \\
(\mu \mathrm{M} / \mathrm{L})\end{array}\end{array}$ & $\begin{array}{c}\text { No. of Flower } \\
\text { Buds/Explant } \\
\text { (Mean } \pm S E \text { ) }\end{array}$ & $\begin{array}{l}\text { No. of Flowers } \\
\text { per explant } \\
\text { (Mean } \pm S E \text { ) }\end{array}$ & $\begin{array}{l}\text { No. of Fruits per } \\
\text { explant } \\
\text { (Mean士SE) }\end{array}$ \\
\hline $26+0$ & $7.4 \pm 1.27 a$ & $4.1 \pm 0.96 a$ & $2.7 \pm 0.95 a$ \\
\hline $28+34$ & $11.6 \pm 1.11 \mathrm{~b}$ & $5.2 \pm 0.97 b$ & $4.8 \pm 0.73 b$ \\
\hline $30+0$ & $14.7 \pm 1.31 \mathrm{c}$ & $6.6 \pm 1.04 \mathrm{c}$ & $5.8 \pm 1.51 \mathrm{c}$ \\
\hline $0+32$ & $12.5 \pm 1.73 d$ & $5.9 \pm 1.24 d$ & $3.3 \pm 1.78 d$ \\
\hline $0+30$ & $8.8 \pm 1.03 a$ & $2.5 \pm 1.01 \mathrm{e}$ & $2.5 \pm 0.61 a$ \\
\hline \multicolumn{4}{|c|}{$\operatorname{SE}($ Means $)=0.44 \mathrm{SE}($ Means $)=0.25 \mathrm{SE}($ Means $)=0.43$} \\
\hline
\end{tabular}

Regarding induction of roots in vitro, the extent of root initiation was almost found equivalent at two combinations: BAP $\left(4.0 \mu \mathrm{ML}^{-1}\right)$ and 2,4-D (5.5 $\left.\mu \mathrm{ML}^{-1}\right)$; BAP $\left(3.5 \mu \mathrm{ML}^{-1}\right)$ and 2,4-D $\left(4.5 \mu \mathrm{ML}^{-1}\right)$ respectively. The first combination yielded maximum number of roots $(54.3 \pm 7.57)$ and the second one generated next best possible result (54.0 \pm 7.43$)$ [Table-3], [Fig-1e]. The first combination could also successfully generate maximum root length of $13.63 \mathrm{~cm}$. Healthy rooted plantlets were best hardened in the substrates consisting of half strength MS with soil, sand, vermicompost and vermiculite (1:1:1:1), and $78.56 \%$ of total hardened plants could be successfully raised in the mail field.

Table 3- Effect of different concentrations of BAP and 2,4-D on in vitro root induction and root length in $C$. chinense $\mathrm{cv}$. Lota Bhot

\begin{tabular}{lccc|} 
S. No. & $\begin{array}{c}\text { Treatments } \\
\text { MS+BAP+2,4-D } \\
(\boldsymbol{\mu M} / \mathrm{L})\end{array}$ & $\begin{array}{c}\text { No. of Roots per Re- } \\
\text { generated Shoot } \\
\text { (Mean } \pm S E)\end{array}$ & $\begin{array}{c}\text { Root Length }(\mathrm{cm}) \\
\text { (Mean } \pm S E)\end{array}$ \\
\hline 1 & $2.0+1.5$ & $25.3 \pm 4.43 \mathrm{a}$ & $3.1 \pm 1.77 \mathrm{a}$ \\
2 & $2.5+2.5$ & $30.4 \pm 6.60 \mathrm{~b}$ & $5.6 \pm 0.86 \mathrm{~b}$ \\
3 & $3.0+3.5$ & $46.3 \pm 4.18 \mathrm{c}$ & $7.5 \pm 1.66 \mathrm{c}$ \\
4 & $3.5+4.5$ & $54.0 \pm 7.43 \mathrm{~d}$ & $12.6 \pm 3.38 \mathrm{~d}$ \\
5 & $4.0+5.5$ & $54.3 \pm 7.57 \mathrm{~d}$ & $13.63 \pm 2.48 \mathrm{e}$ \\
6 & $4.5+6.5$ & $43.3 \pm 3.72 \mathrm{e}$ & $11.54 \pm 2.80 \mathrm{f}$ \\
& & SE(Means) $=3.05$ & SE(Means) $=0.58$ \\
\hline
\end{tabular}

Means followed by the same letters are not significantly different at $p=0.05$

\section{Discussion}

Almost all the species of the genus Capsicum are reluctant to micropropagation. The appropriate amount of media and source of nutrients are the pre-requisites for the establishment of a stable regeneration protocol. Plants of Lota Bhot obtained from DRL, Tezpur had a good potential for callusogenesis when cultured onto full strength MS basal medium. Callus induction medium was standardized with different concentrations of Kin and 2,4-D along with an additional component, $\mathrm{AgNO}_{3}$. Presence of $\mathrm{AgNO}_{3}$ enhances the chances of multiple shoots induction (8.1 \pm 0.74$)$. However, a drastic negative change in the growth curve was observed both in terms of shoot bud formation and shoot length upon altering the concentrations of these components. The present investigation reports for the first time the combined effect of $\mathrm{Kin}, 2,4-\mathrm{D}$ and $\mathrm{AgNO}_{3}$ in the in vitro multiple shoots induction in $\mathrm{C}$. chinense $\mathrm{Cv}$. Lota Bhot although so far there have been several regeneration protocols standardized in different species of Capsicum.

In the genus Capsicum, in vitro flower and fruit inductions are rarely observed. Earlier reports suggest the occurrence of in vitro flowering and fruiting in $C$. frutescens when shoot tips were cultured in a polycarbonate container coupled to an automated plant tissue culture system [16]. Effects of $\mathrm{AgNO}_{3}$ and $\mathrm{CoCl}_{2}$ on in vitro flowering in C.frutescens were broadly elucidated [11]. Reproductive processes like flower induction and fruit development were primarily controlled by $\mathrm{GA}_{3}$ and to some extent $\mathrm{AGNO}_{3}$ as evident from the said investigation. Addition of $\mathrm{GA}_{3}$ to flower and fruit induction media significantly increases the number of flower bud formation and fruit development [Table-2]. $\mathrm{GA}_{3}$ is a potent regulator of flower and fruit induction both in vitro and in vivo. Induction of floral bud in response to the application of $\mathrm{GA}_{3}$ has been recently reported in $C$. annuum [21]. Effect of $\mathrm{GA}_{3}$ was investigated in Lota Bhot. It was able to induce a mean of 14.7 flower bud/explants, 6.6 flowers per explant and 5 . Fruits when applied alone at $30 \mu \mathrm{ML}^{-1} . \mathrm{AgNO}_{3}\left(32 \mu \mathrm{ML}^{-1}\right)$ when applied without $\mathrm{GA}_{3}$ could effectively initiate flower formation $(5.9 \pm 1.24)$ however was not effective enough to generate a good amount of fruits in vitro. $\mathrm{AgNO}_{3}$ is a potent flower inducer in $\mathrm{C}$. frutescens $[11,22]$. Off white flowers (with 5 sepals and 5 petals) remained healthy and in open condition for almost 15 days. A very high dose (above $34 \mu \mathrm{M}$ ) not only reduced the number of flower but also the size of the leaf. Concentration that was lower than $30 \mu \mathrm{M} / \mathrm{L}$, 
did not produce any flower at all. As far the fruit is concerned, the fully matured fruit attained a diameter of approximately $4 \mathrm{~cm}$ and girth of about $4.5 \mathrm{~cm}$ and remain healthy for almost 8-10 $\mathrm{d}$ before it started deteriorating. $\mathrm{AgNO}_{3}$ is considered as a powerful ethylene inhibitor [11]. Ethylene is known to inhibit the action of an enzyme called S-adenosyl methionine decarboxylase which is responsible for production of polyamines that promotes flower induction. Thus the application of silver nitrate promotes in vitro flowering by inhibiting ethylene production.

The combination of BAP $\left(4.0 \mu \mathrm{ML}^{-1}\right)$ and 2,4-D $\left(5.5 \mu \mathrm{ML}^{-1}\right)$ generated highest number of roots $(54.3 \pm 7.57)$ from a single regenerated shoot. Healthy, elongated and branched type of roots were observed in the said investigation.. However, higher doses of BAP generated short and thin roots whereas doses lower than $2 \mu \mathrm{ML}^{-1}$ did produce very fewer roots. Several reports confirms the effectiveness of IBA in promoting in vitro rooting in Chilli has been reported earlier $[4,9,21]$ however there are few reports suggesting the significance of IAA on in vitro rooting in Capsicum [7]. These two rooting hormones were also tried in the experiment but the result obtained with BAP was found to be far more conducive. This may be due to the difference in genotype of the cultivar used in the investigation.

The in vitro rooted Lota Bhot plantlets were transferred to poly house for hardening and acclimatization. Inclusion of bio fertilizer (vermicompost), vermiculite along with sand not only improved the status of the soil but also the health of the plant and increased the percentage of survival $(78.56 \%)$. Technique of micropropagation is quite a new concept for Lota Bhot, a very rare cultivar of $C$. chinense, endemic to Assam. Hence, this communication could be effective enough in opening a way out to explore more about it in the near future.

\section{Conclusion}

The present investigation provides a firsthand report of an efficient in vitro regeneration protocol via leaf explants in $C$. chinense cv.Lota Bhot. Significance of plant growth hormones and $\mathrm{AgNO}_{3}$ in several aspects of in vitro organogenesis including in vitro shoot regeneration, flower and fruit induction has been elaborately described. Lota Bhot being one of the pungent chillies has remarkable potential in the field of food, medicines and pharmaceuticals. Concept of tissue culture in Lota Bhot is quite a new topic so far. The present investigation therefore, brings into light, an innovative approach for exploring more about the crop through micropropagation technique.

\section{Acknowledgement}

Authors thank the Director, Defence Research Laboratory (DRL), Tezpur, Assam for showing keen interest and providing DRDO fellowship. The DRL and Department of Biotechnology (Gauhati University) are duly acknowledged for providing necessary facilities and permission for the work.

\section{Conflicts of Interest: None declared.}

\section{References}

[1] Agrawal S., Chandra N. and Kothari S.L. (1989) Curr. Sci., 57, 1347-1349.

[2] Harvell K.P. \& Bosland P.W. (1997) HortScience., 32, 1992

[3] Sanatombi K. \& Sharma G.J. (2007) Scientia Horticulturae, 113, 96-99.
[4] Sanatombi K. \& Sharma G.J. (2008) Biologia Plantarum, 52(1), 141-145.

[5] Christopher T. \& Rajam M.V. (1994) Plant Cell Tiss. Org. Cult., 38, 25-29.

[6] Ramirez-Malagon R. \& Ochoa-Alejo N. (1996) Plant Cell Rep., 16, 226-231.

[7] Bodhipadma K. \& Leung D.W.M. (2003) In Vitro Cellular and Developmental Biology - Plant, 39(5), 536-539.

[8] Kumar A.M. \& Nair A.S. (2004) Plant Cell Biotech. Mol. Biol., 5 (3\&4), 95-100.

[9] Peddaboina V., Christopher T. \& Subhash K. (2006) Scientia Hort., 107(2), 117-122.

[10]Sanatombi K. \& Sharma G.J. (2006) Journal of Food Agricultural Environment, 4, 205-208.

[11]Sharma A., Kumar V., Giridhar P. \& Ravishankar G.A. (2008) Electronic Journal of Biotechnology, 11(2), 1-6.

[12]Ashrafuzzaman M., Hossain M.M., Ismail M.R., Haque M.S., Shahidullah S.M. and Uz-zaman S. (2009) African Journal of Biotechnology, 8(4), 591-596.

[13]Song J.Y., Sivanesan I, An C.G. \& Jeong B.R. (2010) African Journal of Biotechnology, 9(19), 2768-2773.

[14]Ostroshy M., Moradi K., Nekouei M.K. \& Struik P.C. (2011) Asian Journal of Biotechnology, 3(1), 38-45.

[15]Kehie M., Kumaria S. \& Tandon P. (2012) 3 Biotech, 2(1), 31 35.

[16]Tisserat B. \& Galleta D.P. (1995) HortScience, 30, 130-132.

[17]Rkhis A.C., Maalej M., Messauod S.O. and Drira N. (2006) African Journal of Biotechnology, 5(22), 2092-2302.

[18]Ziv M. \& Naor V. (2006) Propagation of Ornamental Plants, 6 (1), 3-16.

[19]Beyer E.M. (1976) HortScience, 11, 175-196.

[20]Murashige T. \& Skoog F. (1962) Physiol. Plant, 15, 473-497.

[21]Kumari M., Patade V.Y. \& Ahmed Z. (2012) World Journal of Science and Technology, 2(7), 26-35.

[22] Giridhar P., Indu E.P., Vijaya R.D. \& Ravishankar G.A. (2003) Tropical Science, 43(3), 144-146. 